\title{
Assessing the Accuracy of Simulation Model for Septoria Leaf Blotch Disease Progress on Winter Wheat
}

M. El Jarroudi, Université de Liège, 185 Avenue de Longwy, B-6700 Arlon, Belgium; P. Delfosse, Centre de Recherche Public - Gabriel Lippmann, Département Environnement et Agro-biotechnologies (EVA), 41, Rue du Brill, L-4422 Belvaux, Grand-Duchy of Luxembourg; H. Maraite, Unité de Phytopathologie, Université catholique de Louvain (UCL), Croix du Sud 2/3, B-1348 Louvain-la-Neuve, Belgium; L. Hoffmann, Centre de Recherche Public Gabriel Lippmann, Département Environnement et Agro-biotechnologies (EVA), 41, Rue du Brill, L-4422 Belvaux, Grand-Duchy of Luxembourg; and B. Tychon, Université de Liège, 185 Avenue de Longwy, B-6700 Arlon, Belgium

\begin{abstract}
El Jarroudi, M., Delfosse, P., Maraite, H., Hoffmann, L., and Tychon, B. 2009. Assessing the accuracy of simulation model for Septoria leaf blotch disease progress on winter wheat. Plant Dis. 93:983-992.

A mechanistic model, PROCULTURE, for assessing the development of each of the last five leaf layers and the progress of Septoria leaf blotch, caused by Septoria tritici (teleomorph Mycosphaerella graminicola), has been applied on susceptible and weakly susceptible winter wheat (Triticum aestivum) cultivars in two locations (Everlange and Reuland) in Luxembourg over a 3year period (2000 to 2002). A double performance assessment of PROCULTURE was conducted in this study. First, the capability of PROCULTURE to correctly simulate $S$. tritici incidence was checked. Second, the model's ability to accurately estimate disease severity was assessed on the basis of the difference between simulated and observed levels of disease development at each leaf layer. The model accurately predicted disease occurrence in the 2000 and 2002 seasons, on susceptible and semi-susceptible cultivars, with a probability of detection (POD) exceeding 0.90. However, in 2001, even though the POD never fell below 0.90, the false alarm ratio (FAR) was too high to consider the simulations satisfactory. Concerning the evaluation of disease severity modeling, statistical tests revealed accurate simulations performed by PROCULTURE for susceptible cultivars in 2000 and 2002. By contrast, for weakly susceptible cultivars, the model overestimated disease severity, especially for the upper leaves, for the same period.
\end{abstract}

For the past 30 years, leaf blotch disease of wheat (Triticum aestivum L.), caused by the fungus Septoria tritici Roberge ex Desmaz (teleomorph: Mycosphaerella graminicola (Fuckel) Schröter ex Cohn) (37), has increased in severity in the major wheat-growing areas, resulting in significant yield losses $(3,9,10,21,35)$. Yield losses may be substantial, especially when the three upper, youngest leaves present severe symptoms $(35,38)$. S. tritici infections are also common throughout winter and spring in many winter-wheat crops grown in the Grand-Duchy of Luxembourg (G.D. Luxembourg), our study area, causing severe damage during summer if the upper leaves become infected (7).

In the G.D. Luxembourg, fungicide applications are an essential part of cereal crop management. Crop protection relies largely on preventive fungicide applications, and small grain cereals are systemi-

Corresponding author: M. El Jarroudi

E-mail: meljarroudi@ulg.ac.be

Accepted for publication 21 June 2009.

doi:10.1094/PDIS-93-10-0983

(C) 2009 The American Phytopathological Society cally protected with two or three foliar treatments. But environmental concerns and changes in the cost/price ratio for wheat are likely to increase the demand for more accurate identification of spraying needs (31). Integrated pest management requires that pesticides only be applied at particular infection states, and when the pathogen has been correctly identified (42). Unfortunately, due to the great irregularity of Septoria leaf blotch development, risk assessment can be difficult for farmers, resulting in unnecessary chemical applications. To achieve maximum economical and ecological benefits, conceptual approaches, based on phenological and meteorological parameters, may contribute to support decision-making for optimal fungicide applications (42). Treatments against $S$. tritici should thus be applied at the most pathogen-susceptible plant growth stages, particularly in areas where infections do not occur regularly, but where fungicides are nonetheless applied routinely as a protective measure (41).

Common $S$. tritici management aims at keeping the top two leaves free from infection, as these leaves make the main contribution to grain yield $(35,38)$. Other studies demonstrated a significant positive correlation between the loss of active leaf area due to Septoria on the top three leaves and the percent yield loss (29). The flag leaf (i.e., the last leaf to emerge before the ear) is of particular importance because it is the last leaf to senesce, it is atop the canopy intercepting most of the light, and it is in closest vascular proximity to the ear (12). Modeling approaches estimate that at least $45 \%$ of the grain carbohydrate content is derived from the flag leaf (22). The importance of the flag leaf is reflected in the treatments aiming at protecting its photosynthetic activity $(12,35,38)$.

Dispersion of $S$. tritici spores to the flag leaf by rain splash causes only a few direct lesions. Therefore, most forecast systems assume that the main risk of infection to the upper leaves comes from spores developed on the bottom leaves during winter and spring, before stem elongation occurs (13). However, when rainfall is limited, disease spread can be more difficult to predict. Interestingly, it is in these situations that opportunities for reduced fungicide applications might arise for increasing economical benefits. Because of very different developmental rates observed on fields sown at different times, Shaw and Royle (36) suggested that the amount of Septoria inoculum at GS31 (growth stage, first node detectable) (44) was only a partial guide to forecast the inoculum available during the expansion of the last two leaves. The extent to which the fungal population multiplies on the upper leaves is determined by interactions between plant growth rate, rain splash, and to a lesser extent, quantity of inoculum. If the upper leaves are infected early in their life cycles, there are two main reasons why they might suffer more severe damage. First, there is additional time to increase the number of $S$. tritici multiplication cycles on the leaf layer, as well as for disease spread and infection, potentially leading to premature leaf area loss. And second, during early primary infections occurring before stem elongation, spore sources and susceptible tissues are in closer proximity; thus, high energy rain splashes are not required to project spores onto these tissues (36). Both canopy structure and location of inoculum sources change constantly, making the risk evaluation of 
disease progression dynamically complex and specific to each crop canopy (20). The lifetime of a leaf is substantially shortened by secondary infections arising from spores produced by primary lesions within the same canopy leaf layer (36). Therefore, upper layer leaves are at serious risk of yield-limiting epidemics when infection periods occur during the time interval between leaf emergence and roughly two fungal latent periods, after which they would normally die $(20,36)$.

Despite all the existing knowledge about $S$. tritici and its epidemiological cycle, most forecast models have been developed empirically from observations of rainfall and disease incidence (26). These models rely mainly on rainfall measurement, or in some case more comprehensively on weather data, without considering the development of the different leaf layers during stem elongation $(14,25,29,38,40)$.

The aim of this research was to assess the applicability of the simulation software package PROCULTURE outside its geographical area of calibration while using a new set of wheat varieties. PROCULTURE is a concept-oriented model for $S$. tritici epidemiology that takes into account, simultaneously, plant and disease developments $(19,23,24)$. This model, once validated, could be used as an early disease warning system, alerting when to apply fungicides before symptoms become visible.

\section{MATERIALS AND METHODS}

Crop agronomy. Replicated field experiments were established in the sites of Everlange and Reuland (area between 49.46 and $49.45^{\circ} \mathrm{N}$ latitude and 5.57 and $6.14^{\circ} \mathrm{E}$ longitude), G.D. Luxembourg, for

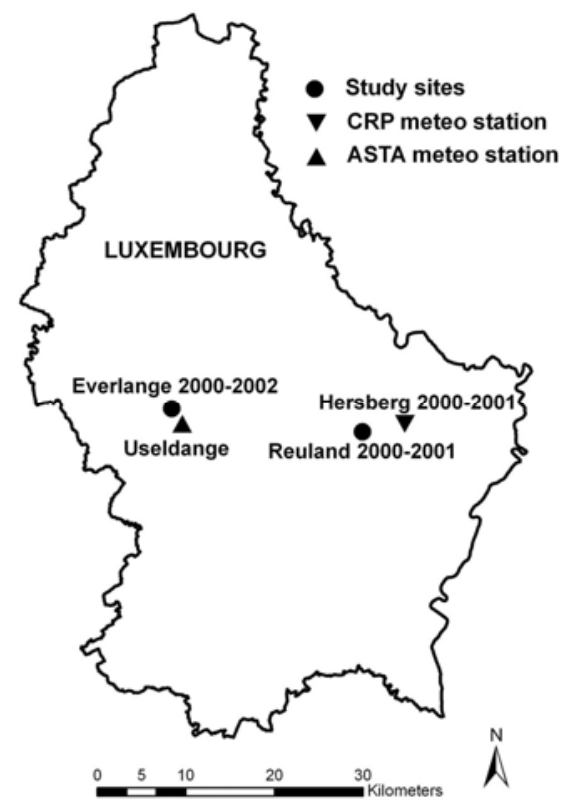

Fig. 1. Locations of both experimental sites (filled circles) and meteorological stations (triangles). CRP: Centre de Recherches PubliquesGabriel Lippmann. ASTA: Administration Des Services Techniques de l'Agriculture. the three growing seasons from 2000 to 2002. Care was taken to select two locations showing drastic differences in both climatic and soil conditions. They belong to two different districts (Luxembourg and Grevenmacher) in G.D. Luxembourg, and these sites are representative of two of the three main cereal areas in the country (7). A weather analysis based on the Fourier transform highlighted a great intraday variation between the two sites (6). For the necessary meteorological data, recordings from the nearby stations of Useldange (maintained by the Administration des Services Techniques de l'Agriculture, Luxembourg) and Hersberg (maintained by the Centre de Recherche Public Gabriel Lippmann, Belvaux) were used (Fig. 1). Crop management data for these experiments are given in Table 1. Experimental fields were typically sown around mid-October. Sowing and harvest methods, as well as crop practices, were representative of usual wheat production in the G.D. Luxembourg. In each location and for each growing season, two wheat cultivars were sown in a randomized block design with four replicates. They included two susceptible cultivars, cv. Achat (2002) and cv. Bussard (2000 and 2001), a semisusceptible cv. Drifter (2002), and a weakly susceptible cv. Dream (2000 and 2001) (1,2). Individual plots measured 8.0 $\times 1.5 \mathrm{~m}$. Plant growth stages (GS) were assessed according to the decimal Zadoks scale (44). All plots received 40 to $70 \mathrm{~kg}$ $\mathrm{N} / \mathrm{ha}$, in the form of ammonium nitrate, at GS25 (main shoot and 5 tillers), followed by 60 to $70 \mathrm{~kg} \mathrm{~N} / \mathrm{ha}$ at GS32 (second node detectable), and a final application of 65 to $95 \mathrm{~kg} \mathrm{~N} / \mathrm{ha}$ at GS59 (emergence of inflorescence completed). Weeds were controlled by one application of preemergence herbicide and one of postemergence (IP flow, 1.0 liter/ha [Isoproturon]; Javelin, 2.0 liter/ha [Didlufenican Isoproturon]). No fungicides were applied on the plots evaluated during this study. Throughout the paper, reference will be made to the specific leaf positions on the wheat stem.
These leaves are numbered relative to the uppermost flag leaf, or L1 (for leaf 1), with the leaf immediately below designated L2, followed by L3, and so on (32).

Crop growth monitoring. Starting with GS30 (pseudo stem erection), identified by plant dissection, crop development was carefully monitored once or twice a week, depending on the site. For each site and each cultivar, 10 plants per replication plot (40 plants in total per cultivar and per site) were randomly selected at each observation throughout the experiment $(20,21)$. L1 was tagged once it had fully emerged, and all previous records were adjusted to ensure that leaves were correctly identified.

Disease monitoring. Again, beginning with GS30 (pseudo stem erection), Septoria tritici blotch incidence (percentage of plants with leaf blotch symptoms) and severity (percentage of leaf area with symptoms showing pycnidia) were determined. At each sampling date and for each plot, 10 main stems were randomly selected in the replication plot at evenly distributed intervals throughout the plot $(20,21)$. Visual estimates of the areas covered by both sporulating $S$. tritici lesions and naturally senescent tissue were made on each of the upper five leaves of each stem. Estimates were made weekly at Reuland and twice per week at Everlange. To achieve maximum accuracy, standard area diagrams for Septoria leaf blotch and other cereal diseases were available to evaluators who assessed the percentage of infection in field (16), and training software programs for assessing disease severity, such as DISTRAIN (39), were used to teach evaluators in disease assessment prior to the experiment.

Description of the PROCULTURE model. The decision support system PROCULTURE $(19,23,24)$ has been developed at the Phytopathology Unit of the Université catholique de Louvain (Belgium) for modeling of Septoria leaf blotch progression in wheat. The model is able to simultaneously estimate the development of the five youngest wheat leaves, as well as the

Table 1. Agronomic details for winter wheat plots used at two experimental sites, Everlange and Reuland, for three growing seasons from 2000 to 2002

\begin{tabular}{lclllll}
\hline Site & $\begin{array}{c}\text { Crop } \\
\text { code }^{\mathbf{a}}\end{array}$ & Date of sowing & $\begin{array}{c}\text { Previous } \\
\text { crops }\end{array}$ & $\begin{array}{c}\text { Date of } \\
\text { GS39 }^{\mathbf{b}}\end{array}$ & $\begin{array}{c}\text { Date of } \\
\text { GS59 }^{\text {c }}\end{array}$ & Nitrogen \\
\hline Everlange & 00-B & 15 Oct. 1999 & Rape & 15 May 2000 & 1 June 2000 & 195 N/ha \\
& 00-D & 15 Oct. 1999 & Rape & 22 May 2000 & 8 June 2000 & 195 N/ha \\
& 01-B & 18 Oct. 2000 & Rape & 25 May 2001 & 7 June 2001 & 230 N/ha \\
& 01-D & 18 Oct. 2000 & Rape & 28 May 2001 & 11 June 2001 & 230 N/ha \\
& 02-Dr & 12 Oct. 2001 & Pea & 16 May 2002 & 5 June 2002 & $175 \mathrm{~N} / \mathrm{ha}$ \\
& 02-A & 12 Oct. 2001 & Pea & 21 May 2002 & 7 June 2002 & $175 \mathrm{~N} / \mathrm{ha}$ \\
Reuland & 00-B & 18 Oct. 1999 & Corn & 20 May 2000 & 2 June 2000 & 200 N/ha \\
& 00-D & 18 Oct. 1999 & Corn & 24 May 2000 & 8 June 2000 & 200 N/ha \\
& 01-B & 28 Oct. 2000 & Corn & 28 May 2001 & 11 June 2000 & n.a. ${ }^{\text {2 }}$ \\
& 01-D & 28 Oct. 2000 & Corn & 5 June 2001 & 18 June 2001 & n.a. \\
\hline
\end{tabular}

a First two numbers of crop code represent last two digits of growing season, followed by a dash and the cultivar code: A, Achat; B, Bussard; D, Dream; Dr, Drifter.

${ }^{\mathrm{b}} \mathrm{GS}=$ growth stage. Flag leaf ligule/collar just visible.

c Emergence of inflorescence completed.

d n.a.: not available. 
S. tritici inoculum available to infect those leaves. This double assessment of crop and disease progress is very useful, as infection has been shown to work its way up from the bottom of the crop, requiring that leaves from different canopy layers are not too far apart (36).

For this model, the occurrence of potential infection periods depends on weather conditions. The PROCULTURE model considers infections to occur when, during a 2-h rainfall event, precipitation for the first hour is at least $0.1 \mathrm{~mm}$ to allow for the swelling of pycnidia, followed by a second hour with at least $0.5 \mathrm{~mm}$ precipitation, to aid in spore release and splashing $(4,19)$. Additionally, following rainfall, relative humidity (RH) must be higher than $60 \%$ during the next $16 \mathrm{~h}$ (19), and the temperature must remain above $4^{\circ} \mathrm{C}$ for $24 \mathrm{~h}$ (4). Each day is assigned a value for the level of potential infection, which corresponds to the number of hours such favorable conditions are met (19). All these model parameters were fine tuned in Belgium thanks to (i) experiments conducted under glasshouse and field conditions, and (ii) a large field-monitoring database extending for a period of almost 10 years (19).

The first symptoms appear at the end of the infection latency period. This period is calculated with Shaw's equation (33) and depends on daily temperature conditions. Biological parameters in the model are expressed in thermal time (degree-days) to allow for time values, such as latent and infectious periods, to remain constant throughout the seasons. The use of thermal time requires that time constants for Septoria leaf blotch development and wheat growth rate are proportional to temperature. This is mostly accurate for the latent period of the disease between 0 and $17^{\circ} \mathrm{C}$ (33) and for the growth rate of wheat over a similar temperature range (11).

Leaf expansion follows a simple thermal time, assuming that a leaf is completely developed by 130 degree-days. Infection is considered possible if at least $5 \%$ of the leaf is developed (19). Moreover, for infection of a given leaf layer to occur, PROCULTURE assumes that L4 and L5 are low enough within the canopy so that they can be infected by conidia produced by pycnidia from the bottom leaves, and that L3 can only be infected during its formation by either L5, or most probably by L4. Similarly, L2 can be infected only by symptomatic L4 or L3 (23).

Table 2. Contingency scores used to test simulation results versus infection occurrences

\begin{tabular}{lcccc}
\hline & & \multicolumn{2}{c}{ Observed values } & \\
\cline { 3 - 4 } & & yes & no & Total simulated \\
\hline Simulated values & yes & $\mathrm{a}$ & $\mathrm{b}$ & $\mathrm{a}+\mathrm{b}$ \\
& no & (hits) & (false alarms) & $\mathrm{d}$ \\
& & (misses) & (correct rejections) & \\
Total observed & $\mathrm{a}+\mathrm{c}$ & $\mathrm{b}+\mathrm{d}$ & \\
\hline
\end{tabular}

The model is run from the beginning of the crop's cycle with hourly rainfall, air temperature, and relative humidity as input data provided by automatic weather stations. Autumn and winter weather conditions are considered by the model because they give general qualitative information on the potential inoculum available for the crop sensitive period, but the actual initialization of the model occurs when L3 starts its growth. For accurate disease modeling, the set of initial conditions includes L3 development and Septoria leaf blotch severity (\% diseased leaf area). Starting with these initial conditions, the model simulates phenology and the disease progression on the various foliar stages. The model allows simulation of actual (i.e., visible symptoms) and latent (in incubation, not yet visible) infections by using recorded (current) and normal (average on 6 years) meteorological data. It also provides a prediction of disease severity by using the same normal meteorological data (19).

Model assessment. A double assessment was applied in this study. The first refers to PROCULTURE's capability to correctly simulate the occurrence expression of $S$. tritici infections on leaf layers at the end of the latency period, with the assumption that inoculum potential was present (19). Assessing infection is of utmost importance since it is a key variable for optimizing fungicide spraying time in early warning systems $(19,23,24)$. This evaluation is based on contingency scores for the variables' probability of detection (POD), false alarm ratio (FAR), and critical success index (CSI) of $S$. tritici infection (Table 2). These statistical scores were calculated using the following formulas: $\mathrm{POD}=a /(a+c)$; FAR $=$ $b /(a+b) ; \operatorname{BIAS}=(a+b) /(a+c)$, and CSI $=$ $a /(a+b+c)(43)$, where $a=$ infections both observed and simulated, $b=$ infections simulated but not observed, and $c=$ infections observed but not simulated.

Regarding field observations, an infection event is considered when symptoms appear after a disease latent period, which has been calculated by the model, and then significantly increase in severity between two successive observations. A comparison test ( $t$ test) with a threshold of $\alpha=0.05$ is performed on these consecutive field observation values to verify the significance of the increment. This means that when the severity level is low (between 0 and 10 to $15 \%$ of severity), a new infection will be assumed if lesions increase more that $1 \%$ between two observations. When severity level is higher than 15 to $20 \%$, the increase should be higher than $10 \%$ to be significant (23). This is due to the fact that the increase in disease severity (percentage of leaf area affected by the disease) is much slower if it resulted from a primary infection than if it is caused by several local secondary infections as described by Shaw and Royle (36).

This method makes it possible to estimate the POD, FAR, and CSI scores defined above (19). It is important to note that between two field observations, two or three latency periods can be expressed. Therefore, additional field observations were made in the two test sites when the model simulated the first appearance of the disease on leaves L5 to L1 to verify if the model is well synchronized with reality.

A second assessment concerns disease severity estimation, and is based on the difference between simulated and observed levels of disease development at each leaf layer. Visual estimates of the area covered by sporulating $S$. tritici lesions on each of the five upper leaves, L5 to L1, are compared with values simulated by the model. Statistical methods used for this test include analyses of variance (ANOVA) using the general linear model (GLM) procedure of the SAS System (Statistical Analysis System software package version 9.01; SAS Institute Inc., Cary, NC), correlation, and regression analyses.

To assess forecasting performance, two basic accuracy estimators are calculated: mean error (ME) and mean absolute error (MAE). The ME tests the incidence and trend of forecast bias errors. A positive ME value indicates an average overestimation of disease level; statistical $t$ tests $(t)$ are used to evaluate whether forecast bias errors are significant. When disease severity, both simulated and observed, was equal to $0 \%$, the data were only taken once into account to generate honest level of correlation when comparing simulated against observed values. $F$ tests are used to determine statistically significant differences for each of the five upper leaves. The ME is defined as:

$$
\mathrm{ME}=1 / T \sum_{t=1}^{T}\left(F_{t}-A_{t}\right)
$$

where $T=$ number of observations, $A_{t}=$ actual data, $F_{t}=$ forecast of component, and $t=$ time.

The MAE determines the magnitude of forecast errors, assuming that the severity of a forecast error increases linearly (e.g., a $2 \%$ error is twice as severe as a $1 \%$ error). It is calculated as:

$$
\text { MAE }=1 / T \sum_{t=1}^{T}\left|F_{t}-A_{t}\right|
$$

\section{RESULTS}

Field observations revealed significant differences among varieties and years, and 
a significant interaction between years and sites $(P<0.001)$. The results of the field monitoring of visually estimated leaf area covered by $S$. tritici lesions are summa- rized in Table 3. At Everlange, in 2000, for all varieties, periods of high infection probability were recorded during L5, L4, and L3 emergence (Fig. 2, Table 3). This allowed for primary and secondary infections on L5, and primary infections on L4 and L3. From the beginning of L2 emergence, during the 10 initial days of May,

Table 3. Visually estimated leaf area (\%) covered by sporulating Septoria tritici lesions on L5 to L1, for the four winter wheat cultivars Achat, Bussard, Dream, and Drifter, between 2000 and 2002, at the trial sites of Everlange and Reuland

\begin{tabular}{|c|c|c|c|c|c|c|c|c|c|c|c|c|c|c|c|c|c|c|c|c|c|c|c|}
\hline \multirow{2}{*}{$\begin{array}{r}\text { Year, site, } \\
\text { cv., date }\end{array}$} & \multirow{2}{*}{\multicolumn{2}{|c|}{$\begin{array}{c}\text { April } \\
16\end{array}$}} & \multicolumn{8}{|c|}{ May } & \multicolumn{9}{|c|}{ June } & \multicolumn{4}{|c|}{ July } \\
\hline & & & 6 & 8 & 11 & 15 & 18 & 22 & 25 & 29 & 1 & 5 & 8 & 12 & 15 & 19 & 22 & 26 & 29 & 3 & 6 & 10 & 13 \\
\hline \multicolumn{24}{|l|}{2000} \\
\hline Everlange & L1 & - & - & - & - & - & - & - & - & $0.3^{* a}$ & 1.0 & 2.0 & 2.0 & $6.0^{*}$ & 10 & 15 & $26^{*}$ & $42^{*}$ & 43 & 46 & 46 & 47 & $68^{*}$ \\
\hline Bussard & L2 & - & - & - & - & - & - & - & - & $2.0^{*}$ & 4.0 & $11^{*}$ & 15 & $22 *$ & 29 & $42 *$ & $60^{*}$ & $72^{*}$ & 72 & 75 & 78 & 78 & $93^{*}$ \\
\hline \multirow[t]{3}{*}{15 Mayb $^{\mathrm{b}}$} & L3 & - & - & - & $5.0^{*}$ & 4.0 & 4.0 & 5.0 & 6.0 & $15^{*}$ & 18 & $35^{*}$ & 44 & $52 *$ & 55 & 56 & $67 *$ & $77^{*}$ & 77 & 80 & - & - & - \\
\hline & $\mathrm{L} 4$ & - & $1.0^{*}$ & $5.0^{*}$ & $18^{*}$ & 20 & 22 & 24 & 26 & $54 *$ & 56 & $76^{*}$ & 84 & 84 & 82 & 83 & $91^{*}$ & $97^{*}$ & 98 & 100 & - & - & - \\
\hline & L5 & - & $3.0^{*}$ & $18 *$ & $56^{*}$ & 59 & 61 & 63 & 66 & $76^{*}$ & 80 & - & - & - & - & - & - & - & - & - & - & - & - \\
\hline Everlange & L1 & - & - & - & - & - & - & - & - & - & - & 0.2 & 0.5 & $1.0^{*}$ & 3.0 & 4.0 & $5.0^{*}$ & $9.0^{*}$ & 10 & 13 & 14 & 16 & $28 *$ \\
\hline Dream & L2 & - & - & - & - & - & - & - & - & - & $0.3 *$ & 2.0 & 3.0 & $4.0^{*}$ & 7.0 & 9.0 & $20^{*}$ & $38^{*}$ & 37 & 41 & 42 & 42 & $66^{*}$ \\
\hline \multirow{4}{*}{$22 \mathrm{May}^{\mathrm{b}}$} & L3 & - & - & - & $0.5^{*}$ & 1.0 & 1.0 & 1.0 & 1.0 & 1.0 & 2.0 & $6.0 *$ & 10 & $15^{*}$ & 19 & $26^{*}$ & $37^{*}$ & $50^{*}$ & 52 & 57 & 64 & 65 & - \\
\hline & L4 & - & $0.1 *$ & $1.0^{*}$ & $4.0 *$ & 4.0 & 4.0 & 4.0 & 5.0 & $9.0 *$ & 12 & $23^{*}$ & 27 & $30 *$ & $43^{*}$ & 47 & $56^{*}$ & $64^{*}$ & 67 & 72 & - & - & - \\
\hline & L5 & - & $4.0 *$ & 6.0 & $24 *$ & 25 & 28 & 30 & 32 & $62^{*}$ & 62 & - & - & - & - & - & - & - & - & - & - & - & - \\
\hline & & 20 & & 8 & & 15 & & 22 & & 29 & & 5 & & & 15 & & & 26 & & 3 & & 10 & \\
\hline Reuland & L1 & - & & - & & - & & - & & $0.3^{*}$ & & $1.0 *$ & & & $17 *$ & & & $45^{*}$ & & 46 & & 48 & \\
\hline Bussard & L2 & - & & - & & - & & $5.0^{*}$ & & 7.0 & & $20^{*}$ & & & $50^{*}$ & & & $79 *$ & & 78 & & 78 & \\
\hline \multirow{3}{*}{20 May $^{\mathrm{b}}$} & L3 & - & & - & & $1.0^{*}$ & & $12^{*}$ & & $34 *$ & & $62 *$ & & & $76^{*}$ & & & $85^{*}$ & & 84 & & 88 & \\
\hline & $\mathrm{L} 4$ & - & & $2.0^{*}$ & & $7.0^{*}$ & & $32 *$ & & $58^{*}$ & & $90^{*}$ & & & 91 & & & $99 *$ & & 99 & & - & \\
\hline & L5 & - & & $22^{*}$ & & $45^{*}$ & & $66^{*}$ & & $80^{*}$ & & - & & & - & & & - & & - & & - & \\
\hline Reuland & $\mathrm{L} 1$ & - & & - & & - & & - & & - & & $0.1^{*}$ & & & $2.0^{*}$ & & & $11^{*}$ & & 14 & & 18 & \\
\hline Dream & $\mathrm{L} 2$ & - & & - & & - & & - & & $0.2^{*}$ & & $1.0^{*}$ & & & $8.0^{*}$ & & & $25^{*}$ & & 27 & & 31 & \\
\hline \multirow{5}{*}{24 Mayb $^{\mathrm{b}}$} & L3 & - & & - & & - & & $2.0^{*}$ & & $6.0^{*}$ & & $14^{*}$ & & & $30^{*}$ & & & $51^{*}$ & & 48 & & 51 & \\
\hline & L4 & - & & - & & $3.0^{*}$ & & $5.0^{*}$ & & $20^{*}$ & & $49^{*}$ & & & $62 *$ & & & $82^{*}$ & & 80 & & - & \\
\hline & L5 & - & & $2.0^{*}$ & & $15^{*}$ & & $29^{*}$ & & $53^{*}$ & & - & & & - & & & - & & - & & - & \\
\hline & & \multicolumn{2}{|c|}{ April } & \multicolumn{7}{|c|}{ May } & \multicolumn{8}{|c|}{ June } & \multicolumn{5}{|c|}{ July } \\
\hline & & 9 & 23 & 4 & 7 & 10 & 14 & 17 & 28 & 31 & 5 & 7 & 11 & 14 & 18 & 21 & 25 & 28 & 2 & 5 & 9 & 12 & 19 \\
\hline
\end{tabular}

2001

$\begin{array}{lllllllllllllllllllllllll}\text { Everlange L1 } & - & - & - & - & - & - & - & - & 0.1 * & 0.2 & 0.7 & 0.4 & 0.4 & 0.3 & 0.2 & 0.1 & 1.0 & 2.0 & 10 * & 12 & 18^{*} & 20 & 40 *\end{array}$ $\begin{array}{lllllllllllllllllllllllll}\text { Bussard L2 } & - & - & - & - & - & - & - & - & 0.8^{*} & 0.3 & 2.0 & 1.0 & 1.0 & 1.0 & 1.0 & 2.0 & 7.0^{*} & 8.0 & 31 * & 34 & 56^{*} & 59 & 82 *\end{array}$

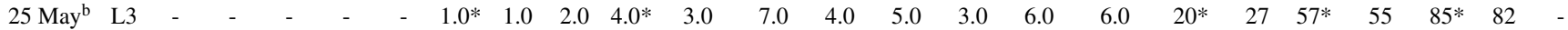
\begin{tabular}{lccccccccccccccccccccccc}
$\mathrm{L} 4$ & - & - & - & $2.0^{*}$ & 2.0 & $16 *$ & 13 & 23 & $31 *$ & 26 & 33 & 27 & 32 & 28 & 32 & 27 & $54 *$ & 55 & $88^{*}$ & 83 & - & - & - \\
\hline
\end{tabular} $\begin{array}{lccccccccccccccccccccccc}\mathrm{L} 5 & 0.3^{*} & 4.0^{*} & 4.2 & 23^{*} & 24 & 59^{*} & 60 & 77^{*} & 80 & 77 & 79 & 77 & 82 & 78 & - & - & - & - & - & - & - & - & - \\ \mathrm{L} 1 & - & - & - & - & - & - & - & - & - & - & - & - & - & - & - & - & 0.0^{*} & 0.0 & 1.0 & 1.0 & 0.3 & 0.2 & 5.0^{*}\end{array}$ $\begin{array}{lllllllllllllllllllllllll}\text { Everlange L1 } & - & - & - & - & - & - & - & - & - & - & - & - & - & - & - & - & 0.0^{*} & 0.0 & 1.0 & 1.0 & 0.3 & 0.2 & 5.0^{*}\end{array}$ $\begin{array}{llllllllllllllllllllllllllll}\text { Dream } & \text { L2 } & - & - & - & - & - & - & - & - & 0.3 & 0.2 & 0.3 & 0.3 & 0.1 & 0.2 & 0.3 & 0.3 & 1.0 & 1.0 & 4.0^{*} & 3.2 & 11^{*} & 9.0 & 26 * \\ 28 \text { Mayb }^{\mathrm{b}} & \text { L3 } & - & - & - & - & - & - & 0.1^{*} & 0.5 & 1.0 & 0.5 & 2.0 & 1.0 & 0.4 & 1.0 & 2.0 & 3.0 & 2.0 & 5.0^{*} & 14^{*} & 20 & 23 & 25 & -\end{array}$

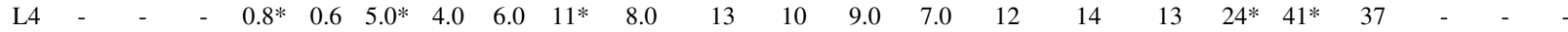
\begin{tabular}{llllllllllllllllllllllllllll} 
L5 & - & $0.5 *$ & 0.2 & $14 *$ & 12 & $41 *$ & 38 & $51 *$ & $66^{*}$ & 68 & 67 & 59 & 60 & 57 & - & - & - & - & - & - & - & - & - \\
\hline
\end{tabular}

\begin{tabular}{|c|c|c|c|c|c|c|c|c|c|c|c|c|c|c|}
\hline & & 9 & 23 & 7 & 14 & 21 & 28 & 5 & 11 & 18 & 25 & 2 & 9 & 19 \\
\hline Reuland & L1 & - & - & - & - & - & - & - & - & - & - & $0.3^{*}$ & $2.0 *$ & $5.0^{*}$ \\
\hline Bussard & L2 & - & - & - & - & - & - & $0.1 *$ & 0.1 & 0.0 & 0.2 & $4.0^{*}$ & $11^{*}$ & $26^{*}$ \\
\hline $28 \mathrm{May}^{\mathrm{b}}$ & L3 & - & - & - & - & $0.1 *$ & 1.0 & 1.0 & 0.3 & 0.4 & 1.0 & $19^{*}$ & $32 *$ & - \\
\hline & L4 & - & - & $1.0^{*}$ & $3.0^{*}$ & $6.0^{*}$ & $8.0^{*}$ & 10 & 8.0 & 7.0 & 11 & $42 *$ & - & - \\
\hline & L5 & - & $4.0^{*}$ & $20^{*}$ & $38^{*}$ & $64 *$ & $71^{*}$ & 69 & 65 & - & - & - & - & - \\
\hline Reuland & L1 & - & - & - & - & - & - & - & - & - & - & - & $1.0^{*}$ & $3.0 *$ \\
\hline Dream & L2 & - & - & - & - & - & - & - & - & - & $0.1^{*}$ & 0.1 & $2.0 *$ & $23^{*}$ \\
\hline 05 June $^{\mathrm{b}}$ & L3 & - & - & - & - & - & $0.2 *$ & 0.1 & 1.0 & 0.2 & 1.0 & $2.0 *$ & $13^{*}$ & - \\
\hline & L4 & - & - & - & 0.1 & $1.0^{*}$ & $2.0^{*}$ & 1.0 & 3.0 & 2.0 & 5.1 & $10^{*}$ & - & - \\
\hline & L5 & - & $1.0 *$ & $11 *$ & 9.0 & 12 & 11 & 7.0 & 15 & - & - & - & - & - \\
\hline & & \multicolumn{3}{|c|}{ April } & \multicolumn{4}{|c|}{ May } & \multicolumn{4}{|c|}{ June } & \multicolumn{2}{|c|}{ July } \\
\hline & & 1 & 19 & & 9 & 16 & 20 & 27 & 3 & & 3 & 20 & 1 & 8 \\
\hline
\end{tabular}

2002

\begin{tabular}{|c|c|c|c|c|c|c|c|c|c|c|c|c|c|c|c|c|c|c|c|c|c|}
\hline Everlange & L1 & - & - & - & - & - & - & - & - & - & $0.1^{*}$ & 1.0 & 2.0 & 1.0 & 2.0 & $5.0^{*}$ & 6.0 & 8.0 & $24^{*}$ & $39 *$ & 39 \\
\hline Achat & L2 & - & - & - & - & - & - & $0.2 *$ & 0.4 & 0.1 & 0.4 & 1.0 & $5.0^{*}$ & $7.0^{*}$ & $17 *$ & $28 *$ & $37 *$ & 51 & $67 *$ & $76^{*}$ & $85^{*}$ \\
\hline \multirow[t]{3}{*}{21 Mayb $^{\mathrm{b}}$} & L3 & - & - & - & - & - & $0.1^{*}$ & 1.0 & $3.0^{*}$ & 3.0 & $5.0^{*}$ & $11^{*}$ & $28^{*}$ & $35^{*}$ & $48^{*}$ & $65^{*}$ & $76^{*}$ & 86 & 90 & 91 & 88 \\
\hline & L4 & - & - & - & - & $0.1 *$ & 0.4 & $4.0 *$ & $10^{*}$ & $19 *$ & $31 *$ & $47 *$ & $69 *$ & $81 *$ & $95^{*}$ & 95 & 97 & 99 & - & - & - \\
\hline & L5 & - & - & $0.3 *$ & 0.1 & 0.1 & 1.0 & $13 *$ & $29 *$ & $50 *$ & $73 *$ & $82 *$ & $94 *$ & 97 & - & - & - & - & - & - & - \\
\hline Everlange & L1 & - & - & - & - & - & - & - & - & - & $0.3 *$ & $1.0 *$ & $2.0^{*}$ & 3.0 & 5.0 & 7.0 & 10 & 17 & 24 & $44 *$ & 42 \\
\hline Drifter & L2 & - & - & - & - & - & - & $1.0 *$ & 2.0 & 2.0 & 2.0 & $3.0 *$ & $5.0^{*}$ & $9.0^{*}$ & $14 *$ & $30 *$ & 39 & 61 & 63 & $76 *$ & 73 \\
\hline \multirow[t]{3}{*}{16 May $^{\mathrm{b}}$} & L3 & - & - & - & - & - & $0.3 *$ & $2.0 *$ & 3.0 & $10 *$ & 10 & $21^{*}$ & $35^{*}$ & $50 *$ & $57 *$ & $75^{*}$ & 79 & 90 & 93 & 96 & 94 \\
\hline & L4 & - & - & - & - & $0.2 *$ & 1.0 & $2.0 *$ & $6.0^{*}$ & $19 *$ & $27 *$ & $46^{*}$ & $68^{*}$ & $81 *$ & $91 *$ & 96 & 95 & 99 & - & - & - \\
\hline & L5 & $1.0^{*}$ & $9.0^{*}$ & 11 & 11 & 9.0 & $19^{*}$ & $31 *$ & 36 & $62 *$ & $72 *$ & $85^{*}$ & $98^{*}$ & 98 & - & - & - & - & - & - & - \\
\hline
\end{tabular}

$\mathrm{a} *=$ Significant difference $(P<0.05)$ between two successive observations. Decimals are only indicated when percentage of disease severity is lower than $10 \%$. ${ }^{\mathrm{b}}$ Date of appearance of the flag leaf ligule/collar (GS39). 
weather conditions did not allow for new infections to occur until the time coinciding with $\mathrm{L} 1$ emergence. At the same time, $\mathrm{L} 2$ and L1 were infected with the inoculum generated on L4 and L3, still located in close proximity. Also in 2000 at Reuland, L5 and L4 were infected during their emergence (Table 3), and inoculum produced on L5 moved to an emerging L3, leading to early infection by the end of April. S. tritici conidia also spread from L4 and L3 to emerging L2 and L1, respectively.

In 2001 at Everlange, for all varieties, L3 emerged around 21 April, when L5 was already symptomatic. $S$. tritici infection was observed on L4 and L3, on 7 May and 14 May, respectively (Table 3). Thus, L3 was infected most probably by inoculum produced on L5 at the end of April. For the susceptible cultivar Bussard, the disease spread from L4 to an emerging L2 during the first 10 days of May. Around 14 May, a few emerging L1 were infected by conidia produced on L3.
For the weakly susceptible cultivar Dream, the fungus spread from L3 to both L2 and L1. At Reuland, in 2001, L5 and L4 were infected during emergence. For Bussard, conidia had already been produced on L5 by 23 April, when L3 was emerging, leading to its early infection. Inoculum from L3, and to a lesser extent from L4, infected L2, and that from L3 most likely infected L1. For the cultivar Dream, Septoria spread from L4 to L3 between 11 May and 20 May, followed by the spread from L3 to L2 and L1 during the first 10 days of June. Symptoms on L2 were first detected on 25 June.

In 2002 at Everlange, L4 and L3 were infected approximately on 17 April with small and distant quantities of inoculum generated on L5. Interestingly, on 20 May, few L2 presented minor symptoms from an infection that should have spread from L4. However, by 3 May, still no symptoms had been observed on L4. This situation may be explained by two plausible assumptions: either a few L2 were infected during emergence at the beginning of May by weak and distant inoculum present on L4 that had not been detected by evaluators, or a horizontal transfer from neighboring plants occurred. Then, following traditional vertical infection patterns, emerging L1 were infected by L3. Precipitation on 19 May was responsible for increased symptoms on L2, and a secondary infection cycle on L3. The fast increasing rate of infection observed on L2 between 16 June and 20 June could be the result of both a secondary infection occurring on 25 and 26 May, and the spread of M. graminicola ascospores, not included in the model.

Assessment of $S$. tritici infection occurrence. In 2000, for the susceptible cultivar Bussard, both in Everlange and Reuland, most infection events predicted by PROCULTURE were detected, with POD values of 0.90 and 0.96 , respectively, and a FAR of 0.00 at both sites (Tables 4 and 5). These results revealed a very good adjustment between the model's simulations and actual field observations. For the

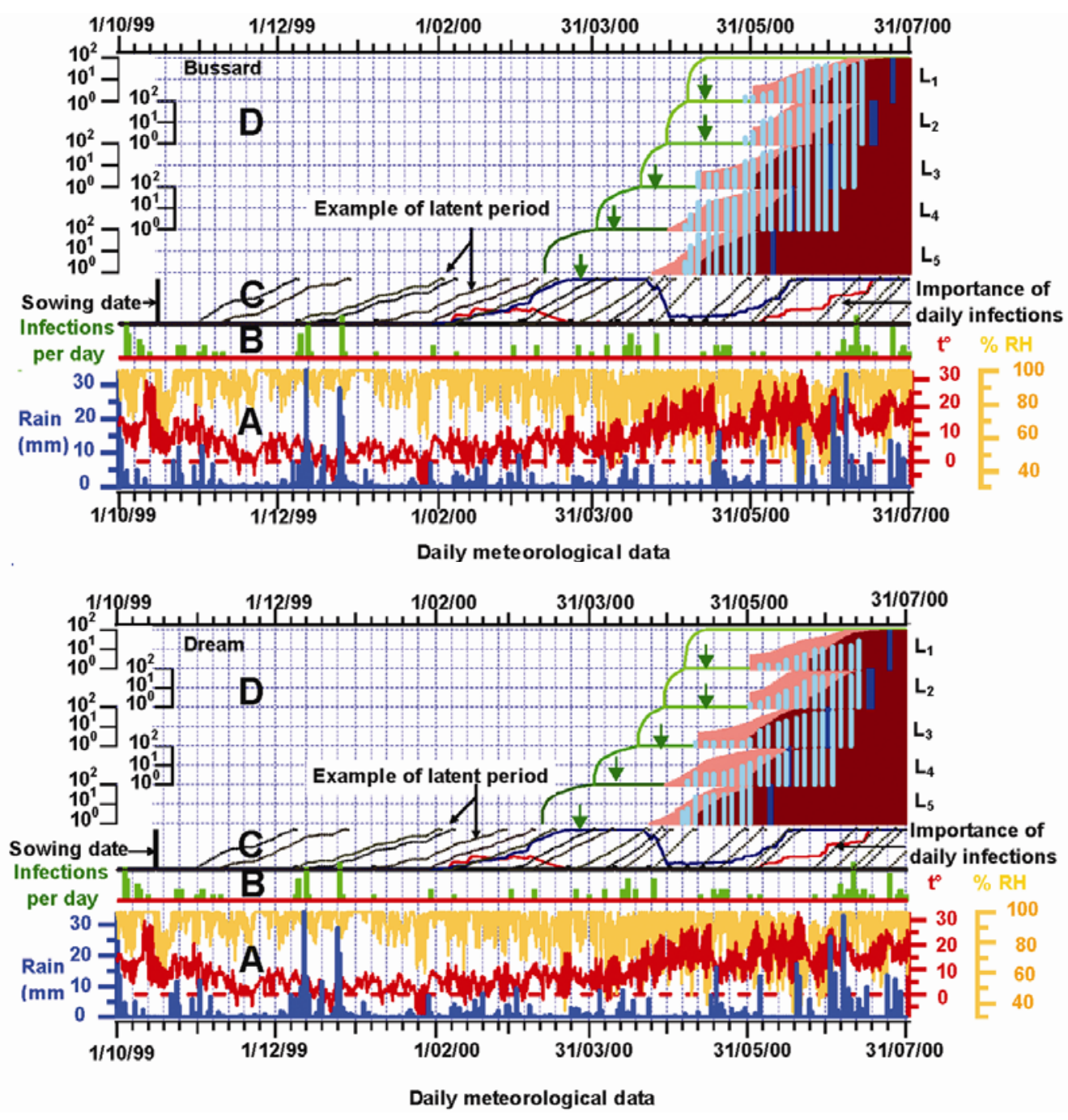

Fig. 2. Output of the Septoria risk simulation model PROCULTURE for 2000 in two cultivars (Bussard and Dream) at Everlange. A, Average daily air temperature $\left({ }^{\circ} \mathrm{C}\right)$, relative humidity $(\%)$, and rainfall $(\mathrm{mm})$ at Useldange, close to Everlange $(500 \mathrm{~m})$. B, Number of hours per day of high probability of infection. C, Latency periods and durations. D, Green lines: scale representing percentage of leaf area development for leaves L5 to L1; pink area: simulated severity of Septoria (\%) on L5 to L1; brown area: simulation of secondary infection expressed on leaves L5 to L1; green arrows: first infection of leaves L5 to L1; light blue bars: real disease observations; dark blue bars: observed leaf senescence. 
five upper leaves, only six and four infection events were detected but not simulated at Everlange and Reuland, respectively (Table 4). Rare infection events were predicted on certain leaves (e.g., L2 in Reuland) 1 to 2 days after the resulting symp- toms were observed in the field. This failure in the simulation forecast could be the result of actual field temperatures differing slightly from the values used by the model to simulate weather conditions, which are temperature averages over the

Table 4. Relationship between forecasted and observed Septoria infection events on leaves L5 to L1 for different winter wheat cultivars at Everlange (2000 to 2002) and Reuland (2000 to 2001)

\begin{tabular}{|c|c|c|c|c|}
\hline Year, site, cv. & Leaves & $\begin{array}{c}\text { Forecasted } \\
\text { and expressed }\end{array}$ & $\begin{array}{l}\text { Forecasted but } \\
\text { not expressed }\end{array}$ & $\begin{array}{l}\text { Expressed but } \\
\text { not forecasted }\end{array}$ \\
\hline \multicolumn{5}{|l|}{2000} \\
\hline Everlange & L5 & 8 & 0 & 2 \\
\hline \multirow{5}{*}{ Bussard } & L4 & 11 & 0 & 1 \\
\hline & L3 & 15 & 0 & 1 \\
\hline & L2 & 10 & 0 & 1 \\
\hline & L1 & 10 & 0 & 1 \\
\hline & Total & 54 & 0 & 6 \\
\hline Everlange & L5 & 5 & 0 & 0 \\
\hline \multirow[t]{5}{*}{ Dream } & L4 & 7 & 2 & 0 \\
\hline & L3 & 7 & 1 & 1 \\
\hline & L2 & 7 & 1 & 1 \\
\hline & L1 & 5 & 2 & 0 \\
\hline & Total & 31 & 6 & 2 \\
\hline Reuland & L5 & 13 & 0 & 0 \\
\hline \multirow[t]{5}{*}{ Bussard } & L4 & 10 & 0 & 0 \\
\hline & L3 & 25 & 0 & 0 \\
\hline & L2 & 20 & 0 & 2 \\
\hline & L1 & 14 & 0 & 2 \\
\hline & Total & 88 & 0 & 4 \\
\hline Reuland & L5 & 8 & 0 & 0 \\
\hline \multirow[t]{5}{*}{ Dream } & $\mathrm{L} 4$ & 13 & 0 & 0 \\
\hline & L3 & 11 & 0 & 1 \\
\hline & L2 & 9 & 0 & 0 \\
\hline & L1 & 4 & 0 & 0 \\
\hline & Total & 45 & 0 & 1 \\
\hline \multicolumn{5}{|l|}{2001} \\
\hline Everlange & L5 & 16 & 1 & 0 \\
\hline \multirow{5}{*}{ Bussard } & L4 & 10 & 3 & 0 \\
\hline & L3 & 7 & 2 & 0 \\
\hline & $\mathrm{L} 2$ & 6 & 0 & 0 \\
\hline & $\mathrm{L} 1$ & 6 & 0 & 1 \\
\hline & Total & 45 & 6 & 1 \\
\hline Everlange & L5 & 10 & 4 & 0 \\
\hline \multirow[t]{5}{*}{ Dream } & L4 & 8 & 1 & 0 \\
\hline & L3 & 6 & 1 & 0 \\
\hline & L2 & 4 & 2 & 0 \\
\hline & L1 & 3 & 1 & 0 \\
\hline & Total & 31 & 9 & 0 \\
\hline Reuland & L5 & 16 & 1 & 0 \\
\hline \multirow[t]{5}{*}{ Bussard } & L4 & 11 & 1 & 0 \\
\hline & L3 & 8 & 2 & 0 \\
\hline & L2 & 7 & 0 & 0 \\
\hline & $\mathrm{L} 1$ & 5 & 1 & 0 \\
\hline & Total & 47 & 5 & 0 \\
\hline Reuland & L5 & 7 & 5 & 1 \\
\hline \multirow[t]{5}{*}{ Dream } & L4 & 5 & 3 & 0 \\
\hline & L3 & 3 & 1 & 1 \\
\hline & $\mathrm{L} 2$ & 5 & 1 & 0 \\
\hline & L1 & 2 & 4 & 0 \\
\hline & Total & 22 & 14 & 2 \\
\hline \multicolumn{5}{|l|}{2002} \\
\hline Everlange & L5 & 8 & 1 & 0 \\
\hline \multirow[t]{5}{*}{ Achat } & L4 & 10 & 0 & 0 \\
\hline & L3 & 13 & 0 & 0 \\
\hline & $\mathrm{L} 2$ & 11 & 1 & 0 \\
\hline & L1 & 8 & 1 & 0 \\
\hline & Total & 50 & 3 & 0 \\
\hline Everlange & L5 & 10 & 1 & 1 \\
\hline \multirow[t]{5}{*}{ Drifter } & L4 & 9 & 1 & 0 \\
\hline & L3 & 12 & 1 & 0 \\
\hline & $\mathrm{L} 2$ & 11 & 1 & 1 \\
\hline & L1 & 7 & 1 & 1 \\
\hline & Total & 49 & 5 & 3 \\
\hline
\end{tabular}

past 6 years. For the weakly susceptible cultivar Dream, the simulation of Septoria leaf blotch symptom occurrence and development was very accurate at Reuland and showed moderate accuracy at Everlange (6 forecasts on 39 events were not expressed). At Reuland, POD $=0.98$, FAR $=0.00$, and CSI $=0.98$, meaning that almost all periods of infections were correctly predicted. At Everlange, the POD was lower but still exceeded 0.90. The FAR was 0.16 , which could be the result of a more frequent sampling rate than at Reuland (twice a week versus once a week), reducing the probability of observing significant symptom evolution between subsequent sampling dates. The cultivar Dream is weakly susceptible to Septoria, and the appreciation of disease development is difficult because of weak symptom progression during a period of primary infection.

In 2001, for the weakly susceptible cultivar Dream, at Everlange, $\mathrm{POD}=1.00$ and $\mathrm{CSI}=0.78$, while at Reuland, $\mathrm{POD}=0.98$ and CSI $=0.58$ (Table 5). The BIAS values, which represent the ratio between the total simulated infection events by the total observed infection events, were 1.3 and 1.5 for Everlange and Reuland, respectively, indicating that the model overestimated the number of infection periods by 30 and $50 \%$ in each case for this weakly susceptible cultivar.

In 2002 at Everlange, the accuracy of the model was validated for both the susceptible cultivar Achat and the semisusceptible cultivar Drifter (Table 5). For Achat, $\mathrm{POD}=1.00, \mathrm{CSI}=0.94$, and FAR $=0.06$. For Drifter, POD $=0.94, \mathrm{CSI}=$ 0.84 , and $\mathrm{FAR}=0.09$.

In 2000 at Everlange, for the susceptible cultivar Bussard, a total of 54 infection events were simulated compared with 45 events simulated in 2001 (Table 4). When considering only the data for the three upper leaf layers, L3 to L1, there were 35 infection periods for Bussard in 2000 and 32 infection periods for Achat (another susceptible cultivar) in 2002, values very different from 19 periods for Bussard recorded in 2001. At Reuland, for the same cultivar, the 47 infection events recorded in 2001 were a decrease from the 88 detected in 2000, mostly because infections fall on the three upper leaves. In 2000, 59 infection events were detected on the three upper leaves of cv. Bussard, compared to 20 in 2001, explaining the weak disease evolution in 2001.

When analyzing FAR data, larger values were observed for the weakly susceptible cultivar Dream than for the susceptible cultivar Bussard. This could be due to a difference in time synchronization between foliar and disease development. Dream had a delayed foliar development, especially by the time of L3 emergence, potentially escaping some of the infection periods simulated by PROCULTURE. 
Assessment of disease severity. In 2000 and 2002, at both sites, for the three upper leaves of susceptible or semi-susceptible cultivars (i.e., Bussard, Drifter, and Achat), the linear regression between simulated and observed values for Septoria was highly significant $(P<0.01)$ and $R^{2}$ (coefficient of determination) explains 87 to $99 \%$ of the variability (Table 6). In addition, the values for ME and MAE were low.

For the weakly susceptible cultivar Dream, in 2000, a good adjustment was observed between simulated and observed values only for the lower leaves L5 and L4 at Reuland, and L5 at Everlange (intercept close to 0 , slope close to 1 , Table 6 ). When the infection extended from L3 to L2, and then to L1, the model tended to overestimate disease occurrences every year, resulting in high values for ME (Table 6, Fig. 3). Even though disease was in fact observed on L2 and L1 on the day predicted by the model, the evolution of the slower in the field. The cultivar Dream differed greatly from other cultivars with regard to its phenology and resistance to Septoria leaf blotch, especially at the top foliar stages.

In 2001, accuracy indicators revealed overestimations of the model. This lack of precision can be partially explained by the effect of weather conditions altering leaf emergence (see discussion).

\section{DISCUSSION}

The extent of $S$. tritici damage greatly depends on disease severity on the flag leaf (L1) $(12,21,34,38)$. A serious reduction in the flag leaf's lifetime is generally caused by large amounts of inoculum generated from a few primary lesions within the same leaf layer, and not from direct spore transport due to rain splash, which causes only a few direct lesions (36). Both the infection on L2 and L1 was 70 and 50\%

flag leaf and L2 are exposed to the risk of being infected between emergence and roughly two disease latent periods before they would naturally senesce. Thus, the strongest risk to a crop occurs when conditions permitting spore transport take place during and shortly after flag leaf emergence (36). Most epidemiological models can simulate such risks, but many remain empirical black boxes using fitted functions between weather conditions, crop characteristics, and epidemic risks $(14,29)$. PROCULTURE $(23,24)$ is a rare epidemiologic, process-oriented model that calculates risk by concurrently simulating crop architecture and disease development. It is capable of analyzing interactions between winter wheat and $S$. tritici development to model disease progression in the crop. Prior to this work, the PROCULTURE model had only been tested on cultivars susceptible to Septoria leaf blotch, and had never been tested outside its calibration area, the Walloon region in Belgium. Moreover, no assessment had been done on the simulated severity levels. In this work, the model's performance was tested by assessing both disease occurrence and simulated severity, in the G.D. Luxembourg, on cultivars with different degrees of susceptibility: susceptible to semisusceptible, and weakly susceptible.

Field observations used for assessment are done one or two times a week while the model runs at daily time step. This may cause some loss of information. For example, in 1 week, the usual observation time step, several infections may occur but the observation method will not tell how many infections there has been during that week.

The model accurately predicted disease occurrence in 2000 and 2002, on susceptible and semi-susceptible cultivars, with a POD exceeding 0.90 at Everlange and reaching 0.96 at Reuland for the suscepti-

Table 5. Principal statistical scores calculated to assess performance of PROCULTURE model for different winter wheat cultivars at Everlange (2000 to 2002) and Reuland (2000 to 2001)

\begin{tabular}{llllll}
\hline & & \multicolumn{4}{c}{ Statistical scores } \\
\cline { 3 - 6 } Year, site & Cultivar & BIAS $^{\mathbf{a}}$ & POD $^{\mathbf{b}}$ & FAR $^{\mathbf{c}}$ & CSI $^{\mathbf{d}}$ \\
\hline 2000 & & & & \\
Everlange & Bussard & 0.90 & 0.90 & 0.00 & 0.90 \\
& Dream & 1.12 & 0.94 & 0.16 & 0.79 \\
Reuland & Bussard & 0.96 & 0.96 & 0.00 & 0.96 \\
& Dream & 0.98 & 0.98 & 0.00 & 0.98 \\
2001 & & & & & \\
Everlange & Bussard & 1.10 & 0.98 & 0.12 & 0.87 \\
Reuland & Dream & 1.30 & 1.00 & 0.22 & 0.78 \\
\multirow{2}{2002}{} & Bussard & 1.10 & 1.00 & 0.10 & 0.90 \\
Everlange & Dream & 1.50 & 0.92 & 0.39 & 0.58 \\
& Achat & 1.00 & 1.00 & 0.06 & 0.94 \\
\hline
\end{tabular}

${ }^{a}$ Ratio between total simulated infection events and total observed infection events. It is a measure of over- or under-estimation.

${ }^{\mathrm{b}}$ Probability of detection is the probability of correctly forecasting the observed event. Range is 0 to 1 . Perfect forecast $=1$.

${ }^{\mathrm{c}}$ False alarm ratio is the number of times an event is forecast but is not observed, divided by the total number of forecasts of that event. Perfect value $=0$.

${ }^{\mathrm{d}}$ Critical success index takes into account both false alarms and missed events. Range is 0 to 1. ble cultivar Bussard. In 2001, even when the POD never fell below 0.90 , the FAR (0.12 and 0.1) was higher than in 2000 and 2002, probably due to particularly bad winter and early spring weather conditions that led to uneven crop developments. When modeling inoculum transfer upward within the plant, PROCULTURE only considers rain splashing, ignoring possible transfer by direct leaf contact. Neither does it consider uneven plant development that may facilitate contact between leaves of different layers among neighboring plants. Lovell et al. (21) reported inoculum transfer between leaves from different layers located in close proximity, even in the absence of either high-volume or highenergy rainfall. For example, within a heterogeneous population with phenological differences of up to one foliar stage, different foliar levels will be infected at the same time. In such cases, the evolution of disease infection within the plant population will differ in accordance with the stages of crop development.

For the semi and weakly susceptible cultivars Drifter and Dream, in 2000 and 2002, high POD values were obtained: 0.94 for Drifter at Everlange in 2002, and 0.98 and 0.94 for Dream in 2000 at Reuland and Everlange, respectively. Also, BIAS values remained close to 1.00 (Table 5). However, in 2001, as was the case for the susceptible cultivars, even though the model yielded high POD values, FAR and BIAS values were much too high due to large amounts of precipitation during winter and early spring. These conditions lead to a very heterogeneous crop formation that allowed for direct contact between leaves of different layers. PROCULTURE should take into account the effect of time distribution of leaf emergence to accurately simulate disease progression. One visual assessment of the heterogeneity in crop development around GS32 (second node detectable) and of actual disease establishment on the lower leaf layers (L4, L5) could significantly improve further simulation of Septoria leaf blotch development on the upper leaves.

Another drawback to PROCULTURE's modeling is that it only considers infections caused by $S$. tritici conidia, the asexual stage of the fungus which causes the most damage. In order to solve this drawback, some authors have recommended the development of modules that take into account the sexual stage of the fungus, $M$. graminicola, to explain sudden changes in disease expression $(5,8,15,18)$.

Overall, in spite of the limitations mentioned above, the 3-year assessment period of Septoria infection data in the G.D. Luxembourg showed that PROCULTURE could be used to predict latency, primary, and secondary infection periods on susceptible cultivars, provided that the input of leaf emergence and development is precise enough. 
Foliar disease management in winter wheat aims at keeping the top two leaf layers healthy, mainly because these upper leaves contribute the most to yield due to shading effects within the canopy $(28,34,38)$. Also, yield losses attributed to Septoria are predominantly caused by a reduction in green leaf area $(27,35)$. In the
G.D. Luxembourg, disease management is primarily achieved through the use of fungicides and, to a lesser extent, diseasetolerant cultivars. Indeed, in their physiological studies, Zuckerman et al. (45) suggested that tolerant wheat cultivars achieved better yield than susceptible ones because of their ability to enhance photo- synthesis in residual green tissues of infected plants.

Concerning the assessment of disease severity modeling for the susceptible cultivars Achat and Bussard in 2000 and 2002, statistical tests revealed accurate simulations performed by PROCULTURE (slope values close to 1 , intercept value close to

Table 6. Statistical test results for comparisons between simulated and observed disease severity at Everlange (2000 to 2002) and Reuland (2000 to 2001) on the last five leaf layers (L5 to L1)

\begin{tabular}{|c|c|c|c|c|c|c|c|c|c|}
\hline \multirow{2}{*}{ Year, site, cv. } & & \multirow[b]{2}{*}{ df } & \multirow[b]{2}{*}{$R^{2}$} & \multirow{2}{*}{$\begin{array}{l}\text { Model significance } \\
\qquad(P>F)^{\mathbf{c}}\end{array}$} & \multicolumn{5}{|c|}{ Regressiona $^{\mathrm{a}}$ parameter tested $(P>\mathbf{l t l})^{\mathrm{b}}$} \\
\hline & & & & & Intercept $^{\mathbf{a}}$ & Slope ${ }^{a, c}$ & $\mathbf{M E}^{\mathbf{d}}$ & $\mathbf{M A E}^{\mathrm{e}}$ & $\mathrm{SE}^{\mathrm{f}}$ \\
\hline \multicolumn{10}{|l|}{2000} \\
\hline Everlange & L5 & 5 & 0.85 & $* *$ & $6.00 \mathrm{NS}$ & $1.00 * *$ & -6.50 & 7.50 & 12.14 \\
\hline \multirow[t]{4}{*}{ Bussard } & L4 & 6 & 0.99 & $* * *$ & $0.10 \mathrm{NS}$ & $0.83 * * *$ & 3.80 & 3.80 & 2.06 \\
\hline & L3 & 8 & 0.99 & $* * *$ & $-0.04 \mathrm{NS}$ & $0.98 * * *$ & 0.30 & 0.50 & 0.67 \\
\hline & L2 & 9 & 0.99 & $* * *$ & $0.36 \mathrm{NS}$ & $0.90 * * *$ & 1.20 & 1.70 & 1.60 \\
\hline & L1 & 9 & 0.99 & $* * *$ & $0.11 \mathrm{NS}$ & $0.89 * * *$ & 0.60 & 0.80 & 1.40 \\
\hline Everlange & L5 & 5 & 0.94 & $* *$ & $2.00 \mathrm{NS}$ & $1.00 * *$ & -4.00 & 5.20 & 6.41 \\
\hline \multirow[t]{4}{*}{ Dream } & L4 & 6 & 0.93 & $* * *$ & $0.50 \mathrm{NS}$ & $0.27 * * *$ & 10.00 & 10.00 & 4.93 \\
\hline & L3 & 8 & 0.93 & $* * *$ & $-1.70 \mathrm{NS}$ & $0.50 * * *$ & 9.40 & 9.50 & 3.50 \\
\hline & L2 & 9 & 0.94 & $* * *$ & $-0.82 \mathrm{NS}$ & $0.47 * * *$ & 9.20 & 9.20 & 3.47 \\
\hline & L1 & 9 & 0.99 & $* * *$ & $-0.60 \mathrm{NS}$ & $0.40 * * *$ & 5.30 & 5.30 & 0.40 \\
\hline Reuland & L5 & 4 & 0.98 & $* *$ & $5.00 \mathrm{NS}$ & $1.00 * *$ & -6.80 & 6.80 & 5.18 \\
\hline \multirow[t]{4}{*}{ Bussard } & $\mathrm{L} 4$ & 4 & 0.98 & $* * *$ & $-2.20 \mathrm{NS}$ & $1.28 * * *$ & -2.70 & 4.70 & 2.87 \\
\hline & L3 & 6 & 0.97 & $* * *$ & $2.60 \mathrm{NS}$ & $1.00 * * *$ & -3.40 & 4.70 & 6.20 \\
\hline & L2 & 7 & 0.99 & $* * *$ & $1.50 \mathrm{NS}$ & $0.98 * * *$ & -1.00 & 1.40 & 1.96 \\
\hline & $\mathrm{L} 1$ & 8 & 0.97 & $* * *$ & $0.28 \mathrm{NS}$ & $0.81 * * *$ & 2.40 & 2.60 & 4.18 \\
\hline Reuland & L5 & 4 & 0.99 & $* * *$ & $-0.44 \mathrm{NS}$ & $0.98 * * *$ & 0.90 & 0.90 & 0.74 \\
\hline \multirow[t]{4}{*}{ Dream } & L4 & 5 & 0.99 & $* * *$ & $0.70 \mathrm{NS}$ & $1.00 * * *$ & -1.40 & 1.40 & 1.88 \\
\hline & L3 & 6 & 0.97 & $* * *$ & $1.50 \mathrm{NS}$ & $0.60 * * *$ & 3.00 & 3.70 & 3.88 \\
\hline & L2 & 8 & 0.99 & $* * *$ & $0.20 \mathrm{NS}$ & $0.40 * * *$ & 10.40 & 10.40 & 3.50 \\
\hline & $\mathrm{L} 1$ & 9 & 0.88 & $* * *$ & $0.97 \mathrm{NS}$ & $0.29 * * *$ & 7.80 & 7.80 & 8.50 \\
\hline \multicolumn{10}{|l|}{2001} \\
\hline Everlange & L5 & 5 & 0.94 & $* *$ & $-0.03 \mathrm{NS}$ & $1.60 * *$ & -14.00 & 14.70 & 5.10 \\
\hline \multirow[t]{4}{*}{ Bussard } & L4 & 5 & 0.88 & $* *$ & $6.85 \mathrm{NS}$ & $0.55 * *$ & 2.30 & 6.90 & 7.84 \\
\hline & L3 & 6 & 0.70 & $*$ & $-0.32 \mathrm{NS}$ & $0.21 *$ & 22.30 & 22.30 & 16.02 \\
\hline & L2 & 5 & 0.77 & $*$ & $5.90 \mathrm{NS}$ & $0.44 *$ & 18.00 & 18.00 & 15.38 \\
\hline & L1 & 6 & 0.96 & $* * *$ & $-4.00 \mathrm{NS}$ & $0.56 * * *$ & 11.30 & 11.30 & 6.32 \\
\hline Everlange & L5 & 6 & 0.93 & $* * *$ & $2.40 \mathrm{NS}$ & $1.58 * * *$ & -10.40 & 10.60 & 4.70 \\
\hline \multirow[t]{4}{*}{ Dream } & L4 & 4 & 0.93 & $* *$ & $2.20 \mathrm{NS}$ & $0.47 * *$ & 3.30 & 3.90 & 3.09 \\
\hline & L3 & 5 & 0.88 & $* *$ & $0.38 \mathrm{NS}$ & $0.08 * *$ & 17.20 & 17.20 & 8.54 \\
\hline & L2 & 5 & 0.74 & $*$ & $-0.07 \mathrm{NS}$ & $0.06 *$ & 14.00 & 14.00 & 11.40 \\
\hline & $\mathrm{L} 1$ & 3 & 0.99 & $* *$ & $-0.60 \mathrm{NS}$ & $0.06 * *$ & 29.00 & 29.00 & 5.29 \\
\hline Reuland & L5 & 4 & 0.83 & $*$ & $17.2 \mathrm{NS}$ & $1.93 *$ & -28.00 & 28.00 & 6.37 \\
\hline \multirow[t]{4}{*}{ Bussard } & L4 & 5 & 0.66 & * & $3.60 \mathrm{NS}$ & $0.28 *$ & 2.40 & 5.30 & 7.11 \\
\hline & L3 & 3 & 0.91 & $*$ & $0.40 \mathrm{NS}$ & $0.02 *$ & 22.00 & 22.00 & 0.14 \\
\hline & L2 & 3 & 0.93 & $*$ & $-0.67 \mathrm{NS}$ & $0.12 *$ & 14.00 & 14.00 & 5.63 \\
\hline & $\mathrm{L} 1$ & 2 & 0.97 & NS & $-0.43 \mathrm{NS}$ & $0.13 \mathrm{NS}$ & 16.00 & 16.00 & 5.51 \\
\hline Reuland & L5 & 6 & 0.36 & NS & $8.40 \mathrm{NS}$ & $0.19 \mathrm{NS}$ & 0.80 & 8.60 & 11.60 \\
\hline \multirow[t]{4}{*}{ Dream } & L4 & 4 & 0.83 & $*$ & $0.53 \mathrm{NS}$ & $0.17 *$ & 4.00 & 4.00 & 2.70 \\
\hline & L3 & 5 & 0.80 & $*$ & $0.06 \mathrm{NS}$ & $0.17 *$ & 4.00 & 4.00 & 1.60 \\
\hline & L2 & 3 & 0.85 & NS & $4.30 \mathrm{NS}$ & $0.40 \mathrm{NS}$ & 20.00 & 20.00 & 11.94 \\
\hline & $\mathrm{L} 1$ & 3 & 0.59 & NS & $0.12 \mathrm{NS}$ & $0.11 \mathrm{NS}$ & 3.20 & 3.20 & 3.00 \\
\hline \multicolumn{10}{|l|}{2002} \\
\hline Everlange & L5 & 11 & 0.98 & $* * *$ & $-5.70 *$ & $1.06 * * *$ & 2.90 & 3.50 & 4.50 \\
\hline \multirow[t]{4}{*}{ Achat } & L4 & 9 & 0.97 & $* * *$ & $4.00 \mathrm{NS}$ & $1.00 * * *$ & -5.00 & 5.50 & 6.00 \\
\hline & L3 & 10 & 0.99 & $* * *$ & $0.22 \mathrm{NS}$ & $0.99 * * *$ & 0.14 & 2.10 & 3.00 \\
\hline & L2 & 9 & 0.98 & $* * *$ & $-0.60 \mathrm{NS}$ & $1.18 * * *$ & -6.00 & 7.10 & 4.60 \\
\hline & L1 & 9 & 0.99 & $* * *$ & $0.39 \mathrm{NS}$ & $0.83 * * *$ & 2.00 & 2.70 & 2.70 \\
\hline Everlange & L5 & 11 & 0.97 & $* * *$ & $-0.09 \mathrm{NS}$ & $0.94 * * *$ & 4.00 & 4.90 & 6.00 \\
\hline Drifter & L4 & 11 & 0.95 & $* * *$ & $-9.20 * *$ & $1.00 * * *$ & 9.00 & 9.00 & 7.82 \\
\hline & L3 & 10 & 0.98 & $* * *$ & $-10.19 * *$ & $1.00 * * *$ & 7.00 & 7.00 & 4.70 \\
\hline & L2 & 13 & 0.95 & $* * *$ & $-5.60 *$ & $0.81 * * *$ & 13.10 & 13.30 & 8.62 \\
\hline & L1 & 9 & 0.90 & $* * *$ & $-3.40 \mathrm{NS}$ & $0.60 * * *$ & 17.00 & 17.00 & 8.80 \\
\hline
\end{tabular}

${ }^{\text {a }}$ Regression equations were $y=$ slope $x+$ intercept, $y=$ observed disease (\%), $x=$ simulated disease (\%) by PROCULTURE.

${ }^{\mathrm{b}}$ Estimated value of parameters associated with each term in the model. $P>|\mathrm{t}|$ : is the $P$ value associated with the $t$ statistic.

${ }^{c} P$ value associated with $F$ value (this ratio compares variability explained by regression line to variability unexplained by regression line). Significance levels: $*=P<0.05 ; * *=P<0.01 ; * * *=P<0.001 ;$ and NS $=P>0.05$.

${ }^{\mathrm{d}}$ Mean error $(\%)$.

e Mean absolute error (\%).

${ }^{\mathrm{f}}$ Standard error is the standard deviation of a population of sample means, rather than of individual observations. 
0, Table 6). However, in 2001, because of the unusual winter weather, the model tended to overestimate severity.

For the weakly susceptible varieties Dream (2000 and 2001) and Drifter (2002), the model also provided overestimations, especially for the upper leaves, L3 to L1 (slope values close to or below 0.5 ). Rapilly (30) reported that the upper leaves of this variety displayed higher resistance levels to Septoria leaf blotch than the lower leaves and that the relative humidity parameters used to forecast an infection on the lower leaves may probably not apply to the upper ones, which are exposed to more rapid evaporation of the water film. The three types of resistance to Septoria leaf blotch known are: a deceleration in the fungal cycle (33), a reduction in the multiplication rate during the fungal cycle, and a difference in phenological de- velopment, resulting from altered synchronization between leaf emergence and infection periods related to rain occurrence (36). The third explanation is that this particular cultivar is suspected to strengthen resistance.

As found in this study, the assessment of PROCULTURE's simulations of infection occurrence gave encouraging results for susceptible and semi-susceptible cultivars during the years 2000 and 2002, at both Everlange and Reuland. For the same 2 years, disease severity estimates were also satisfactory for those same varieties. On the contrary, the model faced limitations when simulating disease on weakly susceptible cultivars. However, all things considered, the model can be applied to advise farmers when to apply fungicides during stem elongation, when the three upper leaves emerge. In this article, we presented only data originating from plots untreated with fungicides. These data represent only one of the treatments of a larger experiment aiming to compare different time and numbers of fungicide sprayings in different locations in G.D. Luxembourg. One of these treatments was given by the PROCULTURE model that provided the date of a unique spraying to protect the crop. Trials continued to be conducted until 2008 . On average, no spray of fungicides or only one application is required to efficiently control Septoria leaf blotch. In one site (Reuler) located in the north of G.D. Luxembourg (49 45'06.94' $\left.\mathrm{N}, 6^{\circ} 15^{\prime} 40.82^{\prime \prime} \mathrm{E}\right)$, fungicide treatments based on the Septoria risk simulation model were never recommended between 2003 and 2006 and in 2008. This conclusion makes us think that the climatic conditions of this site would be suitable for organic farming.
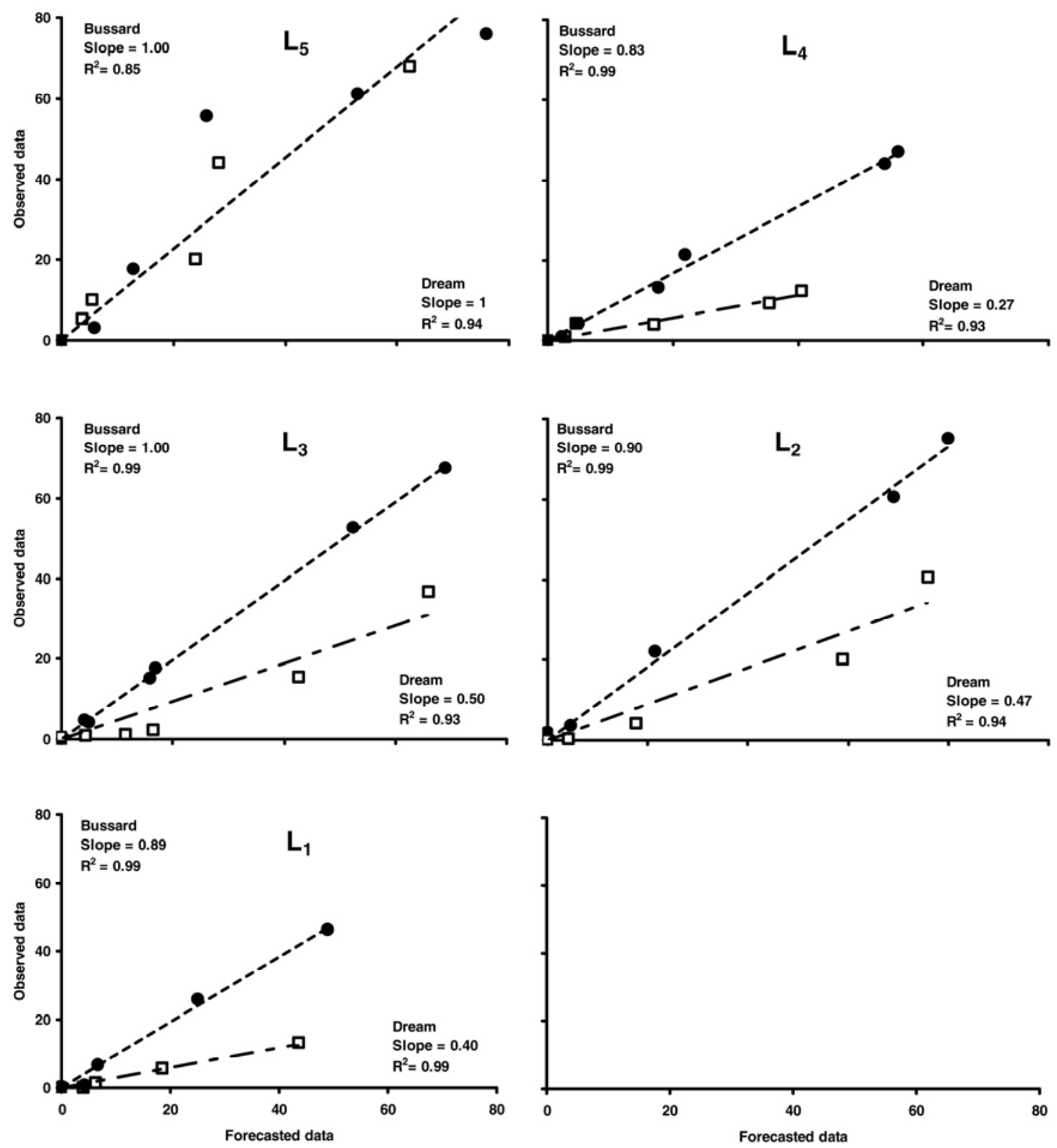

Fig. 3. Relationship between visually estimated area (\%) covered by sporulating Septoria tritici lesions observed at Everlange from 2000 on two varieties

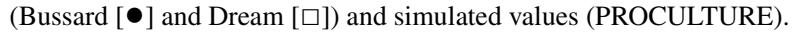


Efforts are now being taken to improve the quantification of disease severity for the weakly susceptible cultivars, and to better define thresholds for fungicide applications. The present PROCULTURE version (2007) allows simulation of Septoria leaf blotch development after GS32 (second node detectable) for cultivars of various resistance levels. Feeding the model with worst-case weather scenarios (19) or with 7 day forecasted weather data (Global Forecast System, National Centers for Environmental Prediction) (17) yielded promising results for predicting disease progress and yield loss beyond availability of actual weather data. More precise field data are also being collected for a better distinction between cultivars on the basis of crop structure and fungal latent period, as well as determination of nitrogen application rates.

\section{ACKNOWLEDGMENTS}

We thank the Ministry of Culture, Higher Education, and Scientific Research of the Grand-Duchy of Luxembourg for contributing to the funding of this research. We are grateful to Guy Reiland, Guy Mirgain, Marc Kails, and Alexandre Nuttens for their technical support, and Michel Santer, Marielle Lecomte, Laurent Pfister, and Jean-François Iffly for the meteorological data.

\section{LITERATURE CITED}

1. Anonymous. 2002. BSA, Beschreibende Sortenliste, Getreide, Mais, Ölfüchte, Leguminosen, Hackfrüchte. Deut. Landwirt. GmbH. pp. 10-17.

2. Anonymous. 2008. BSA, Beschreibende Sortenliste, Getreide, Mais, Ölfüchte, Leguminosen, Hackfrüchte. Deut. Landwirt. GmbH. pp. $78-127$.

3. Brokenshire, T. 1975. The role of graminaceous species in the epidemiology of Septoria tritici on wheat. Plant Pathol. 39:376-390.

4. Calay, F., Coquillart, L., Lucas, C., Lemaire, D., Bodson, B., Moreau, J. M., and Maraite, H. 2002. Lessons from year 2001 Mycosphaerella graminicola epidemic on winter wheat in Belgium. Pages 197-204 in: Med. Rijksuniv. Gent Fak. Landbouwkd Toegep. Biol. Wet.

5. Chen, R. S., and MacDonald, B. A. 1996. Sexual reproduction plays a major role in the genetic structure of populations of the fungus Mycosphaerella graminicola. Genetics 142: 1119-1127.

6. El Jarroudi, M. 2005. Evaluation des paramètres épidémiologiques des principales maladies cryptogamiques affectant les feuilles du blé d'hiver au Grand-Duché de Luxembourg: Calibration et validation d'un modèle de prévision. Ph.D. diss. Université de Liège, Arlon.

7. El Jarroudi, M., Tychon, B., and Maraite, H. 2002. Validation of "Proculture" model to predict Septoria tritici on winter wheat in the Grand-Duché of Luxembourg in 2001. Pages 275-276 in: VII Congress of the European Society for Agronomy Book of Proceedings. F. J. Villalobos and L. Testi, eds. Consejeria de Agricultura y Pesca. Congresos y Jornadas. Cordoba, Spain.

8. Eriksen, L., Shaw, M. W., and Ostergard, H. 2001. A model of the effect of Pseudothetia on genetic recombination and epidemic development in populations of Mycosphaerella graminicola. Phytopathology 91:240-248.

9. Eyal, Z. 1999. The Septoria tritici and Stagonospora nodorum blotch diseases of wheat. Eur. J. Plant Pathol. 105:629-641.

10. Eyal, Z., Scharen, A. L., Huffman, M. D., and
Prescott, J. M. 1985. Global insights into virulence frequencies of Mycosphaerella graminicola. Phytopathology 75:1456-1462.

11. Gallagher, J. N. 1979. Fields studies of cereal leaf growth. I. Initiation and expansion in relation to temperature and ontogeny. J. Exp. Bot. 30:625-636.

12. Gooding, M. J., Dimmock, J. P. R. E., France, J., and Jones, S. A. 2000. Green leaf area decline of wheat flag leaves: The influence of fungicides and relationship with mean grain weight and grain yield. Ann. Appl. Biol. 136:77-84.

13. Hansen, J. G., Secher, B. J. N., Jorgensen, L. N., and Welling, B. 1994. Thresholds for control of Septoria spp. in winter wheat based on precipitation and growth stage. Plant Pathol. 43:183-189.

14. Henze, M., Beyer, M., Klink, H., and Verreet, J.-A. 2007. Characterizing meteorological scenarios favorable for Septoria tritici infections in wheat and estimation of latent periods. Plant Dis. 91:1445-1449.

15. Hunter, T., Coker, R. R., and Royle, D. J. 1999. The teleomorphe stage, Mycosphaerella graminicola, in epidemics of Septoria tritici blotch on winter wheat in the UK. Plant Pathol. 48:51-57.

16. James, C. A. 1971. Manual of assessment keys for plant diseases. Canada Department of Agriculture. Publ. No. 1458. American Phytopathological Society, St. Paul, MN.

17. Junk, J., Görgen, K., El Jarroudi, M., Delfosse, P., Pfister, L., and Hoffmann, L. 2008. Operational application and improvements of the disease risk forecast model PROCULTURE to optimize fungicides spray for the Septoria leaf blotch disease in winter wheat in Luxembourg. Adv. Sci. Res. 2:57-60.

18. Kema, G. H. J., Yu, D., Rijkenberg, F. H. J., Shaw, M. W., and Baayen, R. P. 1996. Histology of the pathogenesis of Mycospharella graminicola in wheat. Phytopathology 86:777786.

19. Lemaire, E. D., Amand, O., and Maraite, H. 2003. Evolution of PROCULTURE, a disease risk simulation model for decision taking in Mycosphaerella graminicola control. G. H. J. Kema, M. Van Ginkel, and M. Harrabi, eds. Pages 83-90 in: Global insights into the Septoria and Stagonospora diseases of cereals. Proc. Int. Sympos. Septoria Stagonospora Dis. Cereals, 6th.

20. Lovell, D. J., Parker, S. R., Hunter, T., Royle, D. J., and Coker, R. R. 1997. Influence of crop growth and structure onto the risk of epidemics by Mycosphaerella graminicola (Septoria tritici) in winter wheat. Plant Pathol. 46:126138

21. Lovell, D. J., Parker, S. R., Hunter, T., Welham, S. J., and Nichols, A. R. 2004. Position of inoculum in the canopy affects the risk of Septoria tritici blotch epidemics in winter wheat. Plant Pathol. 53:11-21.

22. Lupton, F. G. H. 1972. Further experiments on photosynthesis and translocation in wheat. Ann. Appl. Biol. 71:69-71.

23. Moreau, J. M., and Maraite, H. 1999. Integration of knowledge on wheat phenology and Septoria tritici epidemiology into a disease risk simulation model validated in Belgium. Asp. Appl. Biol. 55:1-6.

24. Moreau, J. M., and Maraite, H. 2000. Development of an interaction decision-support system on a web site for control of Mycosphaerella graminicola in winter wheat. Bull. OEPV/EPPO 30:161-163.

25. Murray, G. M., Martin, R. H., and Cullis, B. R. 1990. Relationship of the severity of Septoria tritici blotch of wheat to sowing time, rainfall at heading and average susceptibility of wheat cultivars in the area. Aust. J. Agric. 41:307315.

26. Parker, S. R., Lovell, D. J., Royle, D. J., and
Paveley, N. D. 1998. Analysing epidemics of Septoria tritici for improved estimates of disease risk. Page 351 in: Septoria on Cereals: A Study of Pathosystems, ch. 6. J. A. Lucas, P. Bowyer, and H. M. Anderson, eds. IACR Long Ashton Research Station, Bristol, UK.

27. Parker, S. R., Welham, S., Paveley, N. D., Foulkes, J., and Scott, R. K. 2004. Tolerance of Septoria leaf blotch in winter wheat. Plant Pathol. 53:1-10.

28. Paveley, N. D., Lockley, D., Vaughan, T. B., Thomas, J., and Schmidt, K. 2000. Predicting effective fungicide doses through observation of leaf emergence. Plant Pathol. 49:748-766.

29. Pietravalle, S., Shaw, M. W., Parker, S. R., an van den Bosch, F. 2003. Modeling of relationships between wheather and Septoria tritici epidemics on winter wheat: A critical approach. Phytopathology 93:1329-1339.

30. Rapilly, F. 1991. Epidémiologie en pathologie végétale: Mycoses aériennes. Pages 240-261 in: Epidémiologie en pathologie végétale. $L$. T. Doc, ed. Institut National de la Recherche Agronomique INRA, Paris.

31. Robert, C., Bancal, M. O., Nicolas, P., Lannou, C., and Ney, B. 2004. Analysis and modelling of effects of leaf rust and Septoria tritici blotch on wheat growth. J. Exp. Bot. 399:1-16.

32. Shaner, G., and Buechley, G. 1995. Epidemiology of leaf blotch of soft red winter wheat caused by Septoria tritici and Stagonospora nodorum. Plant Dis. 79:928-938.

33. Shaw, M. W. 1990. Effects of temperature, leaf wetness and cultivar on the latent period on Mycosphaerella graminicola on winter wheat. Plant Pathol. 39:255-268.

34. Shaw, M. W., and Royle, D. J. 1989 Airborne inoculum as a major source of Septoria tritici (Mycosphaerella graminicola) infections in winter wheat crops in the U.K. Plant Pathol. 38:35-43

35. Shaw, M. W., and Royle, D. J. 1989. Estimation and validation of function describing the rate at which Mycosphaerella graminicola causes yield loss in winter wheat. Ann. Appl. Biol. 115:425-442.

36. Shaw, M. W., and Royle, D. J. 1993. Factors determining the severity of epidemics of $M y$ cosphaerella graminicola (Septoria tritici) on winter wheat in the U.K. Plant Pathol. 42:882899.

37. Shipton, W. A., Boyd, W. R. J., Rosielle, A. A., and Sheareb, B. L. 1971. The common Septoria diseases of wheat. Bot. Rev. 37:231-262.

38. Thomas, M. R., Cook, R. J., and King, J. E. 1989. Factors affecting development of Septoria tritici in winter wheat and its effect on yield. Plant Pathol. 38:246-257.

39. Tomerlin, J. R., and Howell, A. 1988. DISTRAIN: A computer program for training people to estimate disease severity on cereal leaves. Plant Dis. 72:455-459.

40. Tyldesley, J. B., and Thompson, N. 1980. Forecasting Septoria nodorum on winter wheat in England and Wales. Plant Pathol. 29:9-20.

41. Verreet, J. A., and Hoffmann, G. M. 1990. A biological oriented threshold decision model for control of epidemics of Septoria nodorum in wheat. Plant Dis. 74:701-708.

42. Verreet, J. A., Klink, H., and Hoffmann, G. M. 2000. Regional monitoring for disease prediction and optimization of plant protection measures: The IPM wheat model. Plant Dis. 84:816-826

43. Wilks, D. S. 1995. Statistical Methods in the Atmospheric Sciences. Academic Press, San Diego, CA.

44. Zadoks, J. C., Chang, T. T., and Konzak, C. F. 1974. A decimal code for the growth stages of cereals weeds. Weed Res. 14:415-421.

45. Zuckerman, E., Eshel, A., and Eyal, Z. 1997. Physiological aspects related to tolerance of spring wheat cultivars to Septoria tritici blotch Phytopathology 87:60-65. 